\title{
Integrasi Modul Sumber Daya Manusia dan Pengadaan dengan Pendekatan Enterprise Architecture untuk Meningkatkan Efisiensi Waktu Pelaksanaan Proses Bisnis
}

\section{Integrated Human Resource and Procurement Module with Enterprise Architecture Approach to Improve Efficiency of Execution Time of Business Process}

\author{
Budiwari Rizki Fadilah*, Rachmadita Andreswari, Ridha Hanafi \\ Program Studi Sistem Informasi, Fakultas Rekayasa Industri, Telkom University
}

\section{ARTICLE INFO}

Article history:

Diterima 26-06-2018

Diperbaiki 15-09-2018

Disetujui 29-12-2018

\section{Kata Kunci:}

Sumber Daya Manusia, Pengadaan, integrasi, enterprise architecture, blueprint.

Keywords:

Human Resources, Procurement, integration, enterprise architecture, blueprint.
A BSTRAK

PT Unilon Textile Industries merupakan salah satu perusahaan textile terkemuka yang berada di Bandung. Perusahaan ini sangat memperhatikan mode-mode textile yang mutakhir sehingga selalu mengutamakan produk yang dihasilkan. Untuk dapat menghasilkan produk berkualitas maka dibutuhkan fungsi sumber daya manusia dan fungsi pengadaan yang baik. Dalam mendukung pelaksanaan fungsi tersebut, dibutuhkan teknologi yang saling terintegrasi dan selaras dengan visi dan misi perusahaan. Dalam menyelaraskan proses bisnis dan teknologi yang dibutuhkan perusahaan maka diperlukan suatu perancangan enterprise architecture. Perancangan enterprise architecture dilakukan menggunakan TOGAF ADM karena memiliki metode sistematis. TOGAF ADM dianggap mampu menguraikan kompleksitas pelaksanaan proses bisnis karena dinilai lengkap dari komponen penyusunannya. Dalam penelitian ini perancangan enterprise architecture dilakukan pada fase preliminary, architecture vision, business architecture, information system architecture, technology architecture, opportunities and solution, dan migration planning. Penelitian dilakukan dengan cara membandingkan keadaan eksisting perusahaan dan keadaan target yang diusulkan. Hasil yang didapat dari penelitian ini adalah blueprint IT Roadmap yang mengintegrasikan modul sumber daya manusia dan pengadaan di aplikasi Sistem Informasi Unilon sehingga meningkatkan efisiensi pelaksanaan proses bisnis sebesar $98,88 \%$.

\section{A B S T R A C T}

PT Unilon Textile Industries is one of the leading textile companies located in Bandung. The company is very concerned in current textile modes so it always prioritizes the product which they are produce. To be able to produce quality products, it will require the function of human resources and good procurement function. To support the implementation of these functions, integrated technologies and aligned with vision and mission of the company are required. In aligning the business process and technology in a company, it is necessary to design enterprise architecture. The design of enterprise architecture is done using TOGAF ADM because it has a systematic method. TOGAF ADM is considered able to reduce the complexity of implementation of business process because it is considered complete in constituent components. In this research, the design of enterprise architecture is done in preliminary phase, architecture vision, business architecture, information system architecture, technology architecture, opportunities and solution, and migration planning. Research is done by comparing the existing state of the company and the proposed target situation. The result of this research is blueprint IT Roadmap which is integraed human resource and procurement modules in Unilon Information System application to improve efficiency of execution time of business process as much as $98,88 \%$. 


\section{Pendahuluan}

Penggunaan Teknologi Informasi (TI) yang semakin pesat dapat mempermudah perusahaan dalam menjalankan aktivitas bisnisnya, terutama yang beorientasi terhadap keuntungan [1]. TI dimanfaatkan oleh perusahaan agar seluruh informasi bisnis serta aktivitasnya dapat berjalan secara efektif dan efisien. Semakin kompleks aktivitas bisnis suatu perusahaan tentu membutuhkan TI yang mendukung dalam pencapaian tujuan perusahaan. Untuk membantu perusahaan dalam mengolah data dan informasi maka dibutuhkan suatu perancangan Enterprise Architecture (EA). Tujuan dari enterprise architecture adalah menyelaraskan strategi bisnis dengan pengelolaan TI sesuai dengan goals perusahaan [2].

PT Unilon Textile Industries adalah salah satu perusahaan textile terkemuka di Bandung dan merupakan salah satu perusahaan joint venture antar modal swasta Indonesia dan Jepang yang didirikan berdasarkan UndangUndang Penanaman Modal Asing tahun 1967. Saat ini PT Unilon Textile Industries bergerak dalam bidang pembuatan benang. PT Unilon Textile Industries juga sangat memperhatikan perkembangan mode-mode textile yang mutakhir dan selalu memelihara mutu internasional (ISO 9002) sehingga dapat memenuhi kebutuhan konsumen baik dalam negeri maupun luar negeri. Namun dalam hal pemenuhan kebutuhan sistem informasi, PT Unilon Textile Industries masih terdapat beberapa kendala seperti aktivitas bisnis yang dilakukan secara manual serta belum terintegrasinya antar aplikasi yang digunakan. Integrasi aplikasi memiliki peran penting dalam mengelola dan menyediakan data atau informasi yang telah terformat dengan baik [2].

Fungsi SDM merupakan sebuah fungsi untuk menjalankan misi organisasi yang memiliki peran dalam menghasilkan sumber daya manusia yang berkualitas. Saat ini dalam menjalankan aktivitas bisnisnya penggunaan TI PT Unilon Textile Industries belum mampu menyesuaikan kebutuhan bisnis pada fungsi SDM. Hal ini ditandai dengan adanya penyebaran informasi lowongan kerja yang dilakukan melalui informasi dari pegawai yang telah bekerja di perusahaan tersebut, serta pengecekan berkas lamaran dan pendataan pelamar masih dilakukan dengan cara input manual. Fungsi pengadaan merupakan salah satu fungsi untuk mendukung proses produksi, dimana pada fungsi ini sangat berpengaruh terhadap pemilihan bahan baku dan perlengkapan karyawan seperti alat tulis kantor (ATK) dalam menjalankan proses bisnis perusahaan. Kegiatan fungsi pengadaan dianggap belum optimal karena belum memanfaatkan aplikasi dalam pemesanannya. Pemesanan bahan baku maupun perlengkapan karyawan masih dilakukan secara manual sehingga memungkinkan terjadinya pengisian data secara berulang (double data).

Seperti yang sudah dijelaskan, permasalahan yang terjadi diakibatkan karena aktivitas bisnis yang dijalankan secara manual. Agar permasalahan dapat diselesaikan, akan dilakukan analisis terhadap kondisi perusahaan saat ini dan dibandingkan dengan requirement yang dibutuhkan perusahaan dalam menjalankan aktivitas bisnisnya. Untuk itu diperlukan perancangan enterprise architecture untuk memodelkan serta menyelaraskan aktivitas bisnis perusahaan dan mengintegrasikan teknologi yang digunakan dalam menjalankan proses bisnis.

Dengan adanya perancangan Enterprise Architecture (EA) diharapkan dapat mempermudah dan memberikan solusi terhadap aktivitas bisnis yang dijalankan serta mampu mengelola data fungsi SDM dan pengadaan. Dimana dalam melakukan perancangan EA dibutuhkan framework arsitektur untuk mengembangkan lingkup pembahasan secara luas dan sistematis dari arsitektur-arsitektur yang berbeda meliputi bisnis, data, aplikasi, dan teknologi. Framework yang digunakan pada penelitian ini adalah The Open Group Architecture Framework (TOGAF) dan menerapkan komponen Architecture Develompent Method (ADM) karena sesuai dengan bidang pendidikan, memiliki struktur yang sistematis, serta memiliki tahapan yang lengkap. TOGAF ADM juga dianggap mampu menguraikan kompleksitas karena dinilai lengkap dari komponen penyusunannya dalam membantu pencapaian rencana strategis perusahaan.

\section{Studi Literatur}

\subsection{Enterprise Architecture}

Cecep Rachmat Mardiansyah mendefinisikan enterprise sebagai seluruh komponen dalam organisasi yang saling berkaitan satu sama lain dibawah kontrol dari organisasi tunggal untuk menyediakan sebuah produk atau pelayanan untuk mencapai tujuan organisasi [4]. TOGAF mendefinisikan arsitektur sebagai struktur komponen, hubungan antar stakeholder, dan prinsip serta pedoman yang mengatur desain dan evolusi perusahaan dari waktu ke waktu [3]. Menurut Gundars Osvald, arsitektur enterprise adalah gambaran mengenai rencana untuk mengembangkan sistem [5]. Dapat disimpulkan enterprise architecture adalah komponen sistem dalam perusahaan yang saling terintegrasi satu sama lain guna mencapai tujuan perusahaan yang menghasilkan layanan atau produk sebagai value added pada perusahaan.

\subsection{Kerangka Kerja}

Supply Chain Dalam melakukan perancangan enterprise architecture dibutuhkan suatu kerangka kerja atau disebut framework. Terdapat beberapa macam framework yang dapat digunakan, seperti Zachman Framework, Federal Enterprise Architecture Framework (FEAF), The Open Group Architecture Framework (TOGAF). Menurut Erwin Budi Setiawan, untuk menentukan penggunaan framework dapat dilihat dari kebutuhan dalam menyelesaikan penelitian berdasarkan kriteria berikut : framework masuk akal yang memungkinkan pembuatan arsitektur bersifat deterministik ketika terjadi perubahan, framework harus mudah beradaptasi terhadap perubahan yang terjadi, serta framework tidak bergantung dengan vendor untuk dapat memaksimalkan keuntungan yang didapat oleh perusahaan [6]. Berdasarkan kriteria framework dapat dilakukan perbandingan terhadap beberapa framework yang dapat dilihat pada Tabel I [6]. 
Tabel 1.

Perbandingan Framework Enterprise Architecture

\begin{tabular}{|c|c|c|c|}
\hline & Zachman & FEAF & TOGAF \\
\hline $\begin{array}{l}\text { Definisi arsitektur } \\
\text { beserta } \\
\text { pemahamannya }\end{array}$ & Sebagian & $\mathrm{Ya}$ & $\begin{array}{ll}\text { Ya, terdapat di fase } \\
\text { awal yaitu fase } \\
\text { preliminary }\end{array}$ \\
\hline $\begin{array}{l}\text { Proses arsitektur } \\
\text { menyeluruh }\end{array}$ & $\mathrm{Ya}$ & Tidak & $\begin{array}{l}\text { Ya, fase ADM } \\
\text { merupakan fase yang } \\
\text { sistematis serta } \\
\text { memiliki tahapan } \\
\text { yang lengkap }\end{array}$ \\
\hline $\begin{array}{l}\text { Mendukung evolusi } \\
\text { arsitektur }\end{array}$ & Tidak & $\mathrm{Ya}$ & $\begin{array}{l}\text { Ya, terdapat di fase } \\
\text { migration planning }\end{array}$ \\
\hline Standarisasi & Tidak & Tidak & $\begin{array}{l}\text { Ya, menyediakan } \\
\text { standar informasi }\end{array}$ \\
\hline $\begin{array}{l}\text { Architecture } \\
\text { Knowledge Base }\end{array}$ & Tidak & $\mathrm{Ya}$ & Ya \\
\hline $\begin{array}{l}\text { Pendorong } \\
\text { keberlangsungan } \\
\text { bisnis }\end{array}$ & Sebagian & $\mathrm{Ya}$ & $\mathrm{Ya}$ \\
\hline Masukan teknologi & Tidak & $\mathrm{Ya}$ & $\mathrm{Ya}$ \\
\hline Permodelan bisnis & $\mathrm{Ya}$ & $\mathrm{Ya}$ & Ya \\
\hline $\begin{array}{l}\text { Desain terhadap } \\
\text { peralihan } \\
\text { perancangan }\end{array}$ & Tidak & $\mathrm{Ya}$ & $\begin{array}{l}\text { Ya, pada salah satu } \\
\text { artefak } \\
\text { migration planning }\end{array}$ \\
\hline Neutrality & $\mathrm{Ya}$ & Tidak & $\mathrm{Ya}$ \\
\hline $\begin{array}{l}\text { Memfasilitasi } \\
\text { prinsip arsitektur }\end{array}$ & Tidak & Tidak & $\mathrm{Ya}$ \\
\hline
\end{tabular}

Dari penjabaran Tabel I terlihat perbedaan antara framework zachman, FEAF, dan TOGAF. Sehingga dapat ditarik kesimpulan untuk merancang enterprise architecture pada penelitian ini digunakan framework TOGAF karena dinilai lengkap dari komponen penyusunannya dibandingkan dengan framework lain. Hal ini sesuai dengan kebutuhan dalam melakukan perancangan enterprise architecture pada fungsi SDM dan fungsi pengadaan pada PT Unilon Textile Industries.

\subsection{TOGAF ADM}

The Open Group Architecture Framework (TOGAF) merupakan sebuah framework yang menyediakan metode dan tools yang detail untuk merancang suatu enterprise architecture [3]. TOGAF memiliki 4 domain arsitektur yang telah diterima secara umum dari keseluruhan arsitektur enterprise, diantaranya [3]:

1. Business Architecture

2. Data Architecture

3. Data Architecture

4. Technology Architecture

Salah satu komponen TOGAF yang digunakan dalam penelitian ini adalah Architecture Development Method (ADM). ADM menggambarkan sebuah metode untuk mengembangkan dan mengelola siklus hidup enterprise architecture dan membentuk inti TOGAF [3]. Semua aktivitas yang terdapat dalam ADM dilakukan secara berkelanjutan sehingga memungkinkan organisasi melakukan implementasi proses bisnis target secara terkendali sebagai respon untuk mencapai tujuan bisnis [7]. Tahapan yang digunakan dalam membangun enterprise architecture, yaitu:

a. Preliminary Phase

b. Phase A : Architecture Vision c. Phase B : Business Architecture

d. Phase $C$ : Information System Architecture

e. Phase D: Technology Architecture

f. Phase E : Opportunities and Solution

g. Phase $F$ : Migration Planning

h. Phase $G$ : Implementation Governance

i. Phase H : Architecture Change Management

\section{Metode Penelitian}

\subsection{Model Konseptual}

Model konseptual merupakan gambaran terstruktur yang berisi hubungan antar konsep yang saling terkait dalam membatu menyelesaikan masalah, mengetahui gambaran data yang dibutuhkan, serta hasil dari pengolahan data yang telah didapatkan. Terdapat 3 elemen utama yang menggambarkan alur penelitian, yaitu permasalahan, knowledge base, dan penelitian sistem informasi.

Elemen pertama yaitu permasalahan, dimana permasalahan yang didapatkan dalam penelitian ini adalah belum memaksimalkan penggunaan sistem yang ada sehingga masih terdapat beberapa aktivitas yang dilakukan secara manual, kemudian sistem yang sudah digunakan belum terintegrasi satu sama lain serta belum memiliki dokumen IT. Elemen kedua yaitu knowledge base, didalamnya terdiri dari konsep dan metode yang digunakan untuk mencari data. Konsep dalam penelitian ini adalah integrasi modul sumber daya manusia dan pengadaan dengan permodelan enterprise architecture, lalu metode yang digunakan dalam mengumpulkan data adalah dengan melakukan wawancara, observasi, dan studi literatur. Elemen ketiga yaitu penelitian sistem informasi dimana pada elemen ini menggambarkan artifak-artifak pada TOGAF ADM dari preliminary phase hingga migration planning. Gambar 1 merupakan kerangka kerja TOGAF ADM untuk memberikan solusi terhadap permasalahan pada penelitian ini.

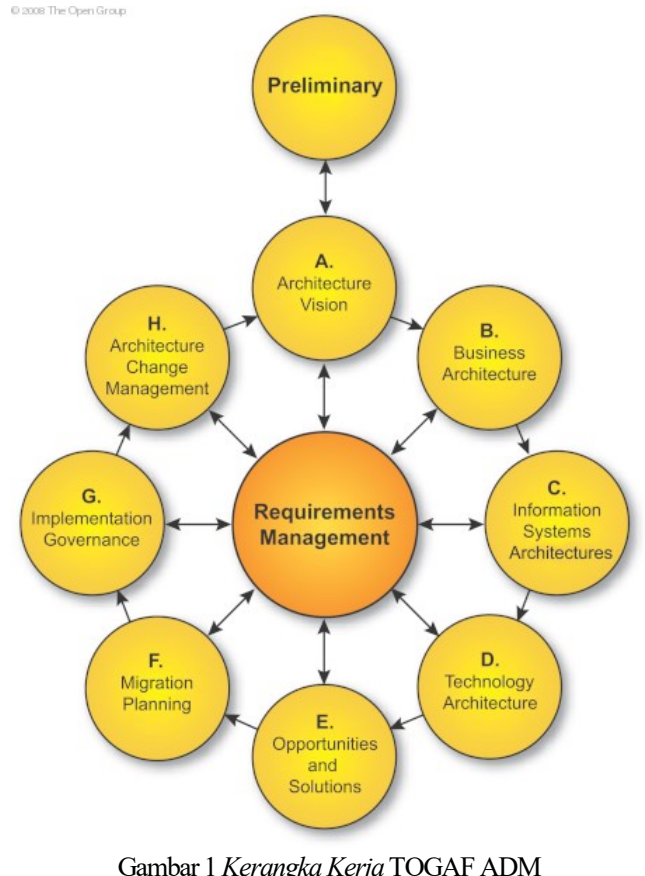

Gambar 1 Kerangka Kerja TOGAF ADM 


\section{Hasil dan Pembahasan}

\subsection{Preliminary phase}

Preliminary phase merupakan tahap awal yang digunakan sebagai tahap persiapan dalam menyusun perancangan enterprise architecture. Dimana dalam fase ini berisi identifikasi terhadap prinsip-prinsip arsitektur dalam pelaksanaan proses bisnis perusahaan. Prinsip arsitektur terdiri dari komponen bisnis, data, aplikasi dan teknologi. Prinsip yang telah diidentifikasi digunakan sebagai acuan dalam melakukan pengembangan enterprise architecture. Prinsipprinsip arsitektur yang digunakan untuk perancangan arsitektur dijabarkan pada Tabel 2.

\subsection{Fase Architecture Vision}

Fase architecture vision merupakan fase awal dari pelaksanaan pengembangan enterprise architecture. Dalam fase ini dilakukan pendefinisian terhadap scope, identifikasi stakeholder, serta penyusunan visi arsitektur perusahaan. Adapun artefak yang dihasilkan antara lain value chain diagram dan solution concept diagram. Value Chain Diagram digunakan untuk memberikan value atau nilai kepada pelanggan dalam bentuk service yang diberikan perusahaan seperti pada gambar 2 .

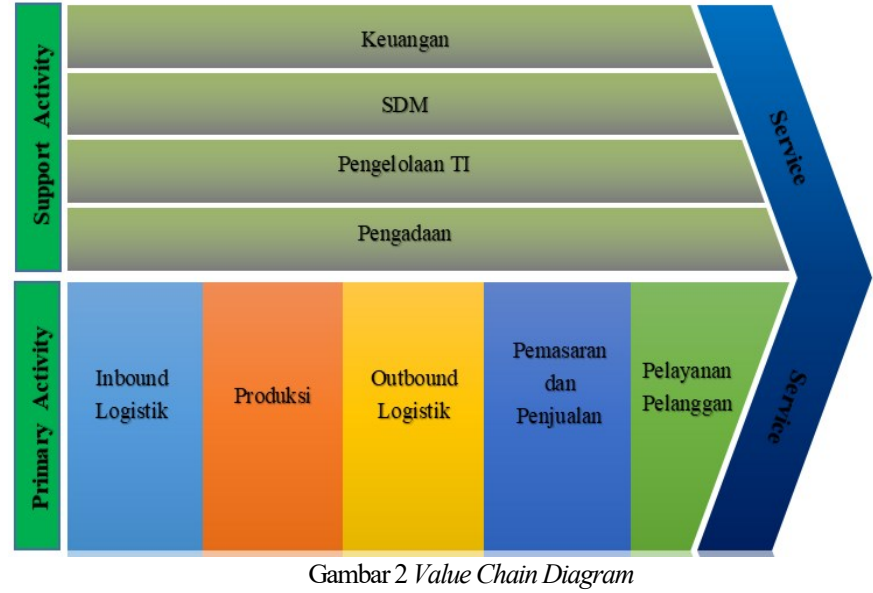

Artefak kedua adalah solution concept diagram menggambarkan sistem yang diusulkan sebagai solusi agar dapat memberikan manfaat bagi perusahaan yang dapat dilihat pada gambar 3 .

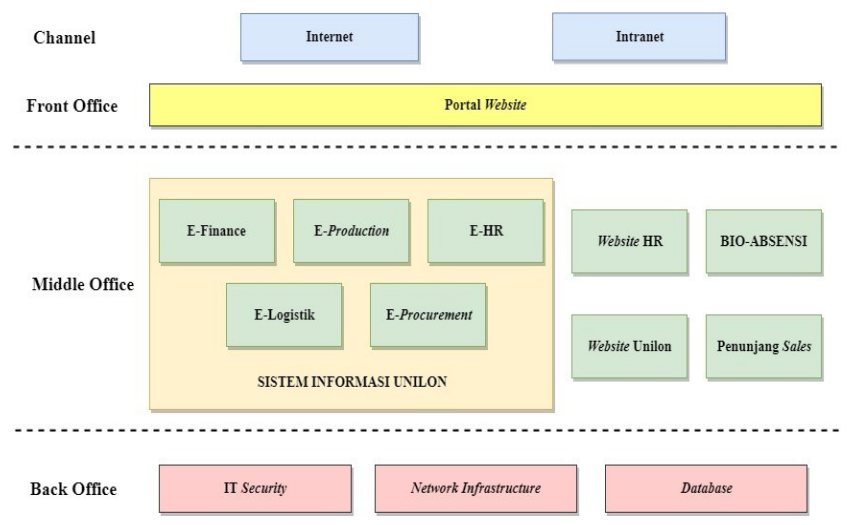

Gambar 3 Solution Concept Diagram
Tabel 2.

Principle Catalog

\begin{tabular}{|c|c|c|}
\hline Arsitektur & Principle & Deskripsi \\
\hline \multirow[t]{6}{*}{$\begin{array}{l}\text { Business } \\
\text { Architecture }\end{array}$} & $\begin{array}{l}\text { Keberlangsungan } \\
\text { Bisnis }\end{array}$ & $\begin{array}{l}\text { Seluruh kegiatan operasional } \\
\text { harus terdokumentasi dan } \\
\text { berjalan sesuai dengan peraturan } \\
\text { walaupun terdapat kendala } \\
\text { internal maupun eksternal }\end{array}$ \\
\hline & $\begin{array}{l}\text { Memaksimalkan } \\
\text { keuntungan }\end{array}$ & $\begin{array}{l}\text { Memaksimalkan proses bisnis } \\
\text { untuk mendapat keuntungan bagi }\end{array}$ \\
\hline & bisnis & $\begin{array}{l}\text { PT Unilon Textile Industries } \\
\text { sehingga dapat menjalin } \\
\text { kerjasama dengan supplier serta } \\
\text { memperluas area pemasaran guna } \\
\text { mendapatkan keuntungan pada } \\
\text { perusahaan }\end{array}$ \\
\hline & $\begin{array}{l}\text { Kepatuhan } \\
\text { terhadap hukum }\end{array}$ & $\begin{array}{l}\text { Seluruh proses bisnis dan tata } \\
\text { kelola perusahaan harus } \\
\text { memenuhi kebijakan dan } \\
\text { peraturan yang ditetapkan oleh } \\
\text { PT Unilon Textile Industries. }\end{array}$ \\
\hline & $\begin{array}{l}\text { Berorientasi } \\
\text { layanan }\end{array}$ & $\begin{array}{l}\text { Memberikan dan meningkatkan } \\
\text { pelayanan pemesanan barang } \\
\text { untuk menjadi } 5 \text { besar industri } \\
\text { tekstil terbaik dunia. }\end{array}$ \\
\hline & $\begin{array}{l}\text { Perlindungan } \\
\text { kekayaan } \\
\text { perusahaan }\end{array}$ & $\begin{array}{l}\text { Melakukan pengelolaan asset } \\
\text { perusahaan dengan baik dan } \\
\text { terstruktur. }\end{array}$ \\
\hline \multirow[t]{6}{*}{$\begin{array}{l}\text { Data } \\
\text { Architecture }\end{array}$} & Aset data & $\begin{array}{l}\text { Data dalam pelaksanaan } \\
\text { operasional merupakan asset } \\
\text { yang dikelola dengan baik dan } \\
\text { dijaga kerahasiaannya. }\end{array}$ \\
\hline & Sharing data & $\begin{array}{l}\text { Data dapat diakses oleh pengguna } \\
\text { yang memiliki hak akses dalam } \\
\text { menunjang proses bisnis. }\end{array}$ \\
\hline & Akses data & $\begin{array}{l}\text { Data dapat diakses dengan mudah } \\
\text { oleh pihak yang memiliki } \\
\text { wewenang untuk mengelola data. }\end{array}$ \\
\hline & Data terpercaya & $\begin{array}{l}\text { Setiap data didapat berdasarkan } \\
\text { fakta dan dapat } \\
\text { dipertanggungjawabkan. }\end{array}$ \\
\hline & Keamanan data & $\begin{array}{l}\text { Seluruh data perusahaan dijaga } \\
\text { keamanannya dari pengguna yang } \\
\text { tidak memiliki hak akses data. }\end{array}$ \\
\hline & Akurasi data & $\begin{array}{l}\text { Data yang dikelola harus sesuai } \\
\text { dengan data yang ada pada } \\
\text { perusahaan. }\end{array}$ \\
\hline \multirow{4}{*}{$\begin{array}{l}\text { Application } \\
\text { Architecture }\end{array}$} & Keamanan & Keamanan aplikasi digunakan \\
\hline & Aplikasi & $\begin{array}{l}\text { untuk mengontrol hak akses dan } \\
\text { pertukaran data di dalam aplikasi. }\end{array}$ \\
\hline & $\begin{array}{l}\text { Kemudahan } \\
\text { penggunaan }\end{array}$ & $\begin{array}{l}\text { Aplikasi mudah digunakan oleh } \\
\text { pengguna dengan adanya training } \\
\text { penggunaan aplikasi. }\end{array}$ \\
\hline & $\begin{array}{l}\text { Hak akses } \\
\text { aplikasi }\end{array}$ & $\begin{array}{l}\text { Menerapkan hak akses pada } \\
\text { setiap pengguna } \\
\text { berdasarkan } \\
\text { perusahaan. }\end{array}$ \\
\hline \multirow[t]{6}{*}{$\begin{array}{l}\text { Technology } \\
\text { Architecture }\end{array}$} & Interoperabilitas & $\begin{array}{l}\text { Penggunaan software dan } \\
\text { hardware pada perusahaan sesuai } \\
\text { dengan standar yang berlaku. }\end{array}$ \\
\hline & $\begin{array}{l}\text { Keamanan } \\
\text { Teknologi }\end{array}$ & $\begin{array}{llr}\begin{array}{l}\text { Teknologi } \\
\text { perusahaan }\end{array} & \text { yang } & \text { digunakan } \\
\text { terjamin }\end{array}$ \\
\hline & & $\begin{array}{l}\text { keamanannya dari pihak yang } \\
\text { tidak memiliki hak akses. }\end{array}$ \\
\hline & $\begin{array}{l}\text { Mendukung } \\
\text { perubahan sesuai } \\
\text { kebutuhan }\end{array}$ & $\begin{array}{l}\text { Perubahan teknologi pada } \\
\text { perusahaan mengikuti kebutuhan } \\
\text { proses bisnis yang dijalankan }\end{array}$ \\
\hline & & Industries. \\
\hline & Kontrol Teknis & $\begin{array}{l}\text { Dilakukan pengecekan secara } \\
\text { rutin. }\end{array}$ \\
\hline
\end{tabular}




\subsection{Fase Business Architecture}

Fase business architecture merupakan identifikasi strategi kebutuhan bisnis yang dijalankan dalam menggambarkan keadaan proses bisnis eksisting perusahaan. Process flow catalog mendeskripsikan business service berdasarkan fungsi bisnis pada penelitian ini yang dapat dilihat pada tabel 3 .

Tabel 3 .

Process Flow Catalog

\begin{tabular}{lll}
\hline \multicolumn{1}{c}{ Fungsi } & \multicolumn{1}{c}{ Business Service } & \multicolumn{1}{c}{ Business Process } \\
\hline Sumber Daya & Pengelolaan Rekrutmen & Rekrutmen Pegawai \\
Manusia & Pengelolaan Absensi & Pengajuan Lembur \\
& Pengelolaan Gaji & Cuti Pegawai \\
& Pengelolaan Jadwal Kerja & Pembajian Pegawai \\
& Pegagaian Jadwal \\
Pengadaan & Pengelolaan Pengadaan & Kerja Shift \\
& Bahan Baku & Pembelian Tunai \\
& & Melalui Supplier \\
& & Pembelian Kredit \\
& & Melalui Supplier \\
& & Pembelian Tunai \\
& & Melalui Penawaran \\
& & Pembelian Kredit \\
& Pelalui Penawaran \\
& ATK & Retur Pembelian \\
& & Pembelian ATK \\
\hline
\end{tabular}

\subsection{Fase Data Architecture}

Fase data architecture merupakan bagian dari fase information system architecture. Fase ini menjelaskan kebutuhan data apa saja yang diperlukan dalam melakukan pengembangan enterprise architecture. Salah satu output yang dihasilkan dari fase ini yaitu data dissemination diagram. Hasil dari fase ini dapat dilihat pada gambar 4 merupakan data dissemination diagram yaitu diagram yang menunjukkan hubungan antara entitas data, layanan bisnis, dan komponen aplikasi pada fungsi SDM dan pengadaan di PT Unilon Textile Industries.

\subsection{Fase Application Architecture}

Fase application architecture merupakan bagian dari fase information system architecture. Fase ini menjelaskan kebutuhan aplikasi apa saja yang diperlukan dalam melakukan pengembangan enterprise architecture. Application communication diagram merupakan diagram yang menggambarkan komunikasi antar aplikasi di dalam sebuah sistem yang saling terintegrasi yang dapat dilihat pada gambar 5 .

\subsection{Fase Technology Architecture}

Fase technology architecture menggambarkan pengembangan terhadap teknologi dalam perusahaan yang meliputi penggunaan software maupun hardware yang dijadikan dasar pengembangan arsitektur. Salah satu artefak dalam fase ini adalah platform decomposition diagram dilihat pada Gambar 6 yang mendeskripsikan platform teknologi dalam mendukung information system architecture yang telah sebelumnya.

Tabel 4.

Implementation Factor Assessment and Deduction Matrix

\begin{tabular}{|c|c|c|c|}
\hline Factor Type & Factor & Description & Deduction \\
\hline \multirow[t]{2}{*}{ Risk } & Bencana alam & $\begin{array}{l}\text { Bencana alam yang mungkin akan terjadi } \\
\text { misalnya gempa bumi, banjir, dan sebagainya }\end{array}$ & $\begin{array}{l}\text { Adanya backup server untuk mem-backup } \\
\text { aplikasi dan data }\end{array}$ \\
\hline & $\begin{array}{l}\text { Kerusakan atau gangguan } \\
\text { pada sistem yang tersedia } \\
\text { dan human error }\end{array}$ & $\begin{array}{l}\text { Kerusakan atau gangguan yang mungkin akan } \\
\text { terjadi karena terdapat kerusakan sistem atau } \\
\text { human error sehingga dapat mengakibatkan } \\
\text { kehilangan data, dll. }\end{array}$ & $\begin{array}{l}\text { Adanya manual book bagi pegawai untuk } \\
\text { mengurangi resiko } \\
\text { menggunakan aplikasi. }\end{array}$ \\
\hline Issue & $\begin{array}{l}\text { Persaingan antar perusahaan } \\
\text { sejenis meningkat }\end{array}$ & $\begin{array}{l}\text { Pasar bebas berdampak adanya daya saing } \\
\text { terhadap penjualan dan pembelian produk yang } \\
\text { dihasilkan oleh perusahaan }\end{array}$ & $\begin{array}{l}\text { Adanya peningkatan terhadap kualitas dan } \\
\text { kuantitas barang yang dihasilkan, penggunaan } \\
\text { jasa, serta tenaga kerja }\end{array}$ \\
\hline \multirow[t]{2}{*}{ Dependencies } & $\begin{array}{l}\text { Ketergantungan terhadap } \\
\text { aplikasi yang ada. }\end{array}$ & $\begin{array}{l}\text { Proses bisnis akan tergantung terhadap aplikasi } \\
\text { yang ada, dan dikhawatirkan jika aplikasi tersebut } \\
\text { terjadi gangguan maka proses bisnisnya tidak } \\
\text { akan berjalan dengan maksimal. }\end{array}$ & $\begin{array}{l}\text { Adanya infrastruktur yang sesuai dan terkelola } \\
\text { dengan baik, sehingga aplikasi yang ada dapat } \\
\text { terjaga dan terhindar dari ganguan. }\end{array}$ \\
\hline & $\begin{array}{l}\text { Ketergantungan } \\
\text { data. }\end{array}$ & $\begin{array}{l}\text { Laporan keuangan tergantung terhadap laporan } \\
\text { dari setiap divisi. }\end{array}$ & 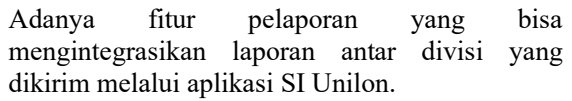 \\
\hline \multirow[t]{2}{*}{ Assumption } & $\begin{array}{l}\text { Pemahaman pegawai } \\
\text { terhadap penggunaan Sistem } \\
\text { Informasi Unilon }\end{array}$ & $\begin{array}{l}\text { Penerapan sistem berupa aplikasi untuk } \\
\text { menunjang proses bisnis perusahaan }\end{array}$ & $\begin{array}{l}\text { Adanya manual book untuk setiap pengguna } \\
\text { aplikasi yang membutuhkan }\end{array}$ \\
\hline & $\begin{array}{l}\text { Pemahaman } \\
\text { terhadap } \\
\text { website HR }\end{array}$ & $\begin{array}{l}\text { Penerapan website HR yang menfasilitasi pelamar } \\
\text { yang mengikuti rekrutmen. }\end{array}$ & $\begin{array}{l}\text { Adanya halaman website yang memberikan } \\
\text { informasi mengenai tata cara pengisian untuk } \\
\text { form rekrutmen. }\end{array}$ \\
\hline Actions & Perbedaan format data & $\begin{array}{l}\text { Format data pada aplikasi dan website memiliki } \\
\text { perbedaan. }\end{array}$ & $\begin{array}{l}\text { Adanya ketentuan format yang disediakan oleh } \\
\text { perusahaan }\end{array}$ \\
\hline Impact & $\begin{array}{l}\text { Implementasi } \\
\text { informasi Unilon } \\
\text { website HR }\end{array}$ & $\begin{array}{l}\text { Implementasi sistem informasi dan website HR } \\
\text { membantu proses bisnis perusahaan menjadi lebih } \\
\text { efektif dan efisien }\end{array}$ & $\begin{array}{l}\text { Adanya bagian IT yang mengelola dan } \\
\text { memelihara infrastruktur teknologi sehingga } \\
\text { penggunaan IT dapat beroperasi secara terus } \\
\text { menerus. }\end{array}$ \\
\hline
\end{tabular}




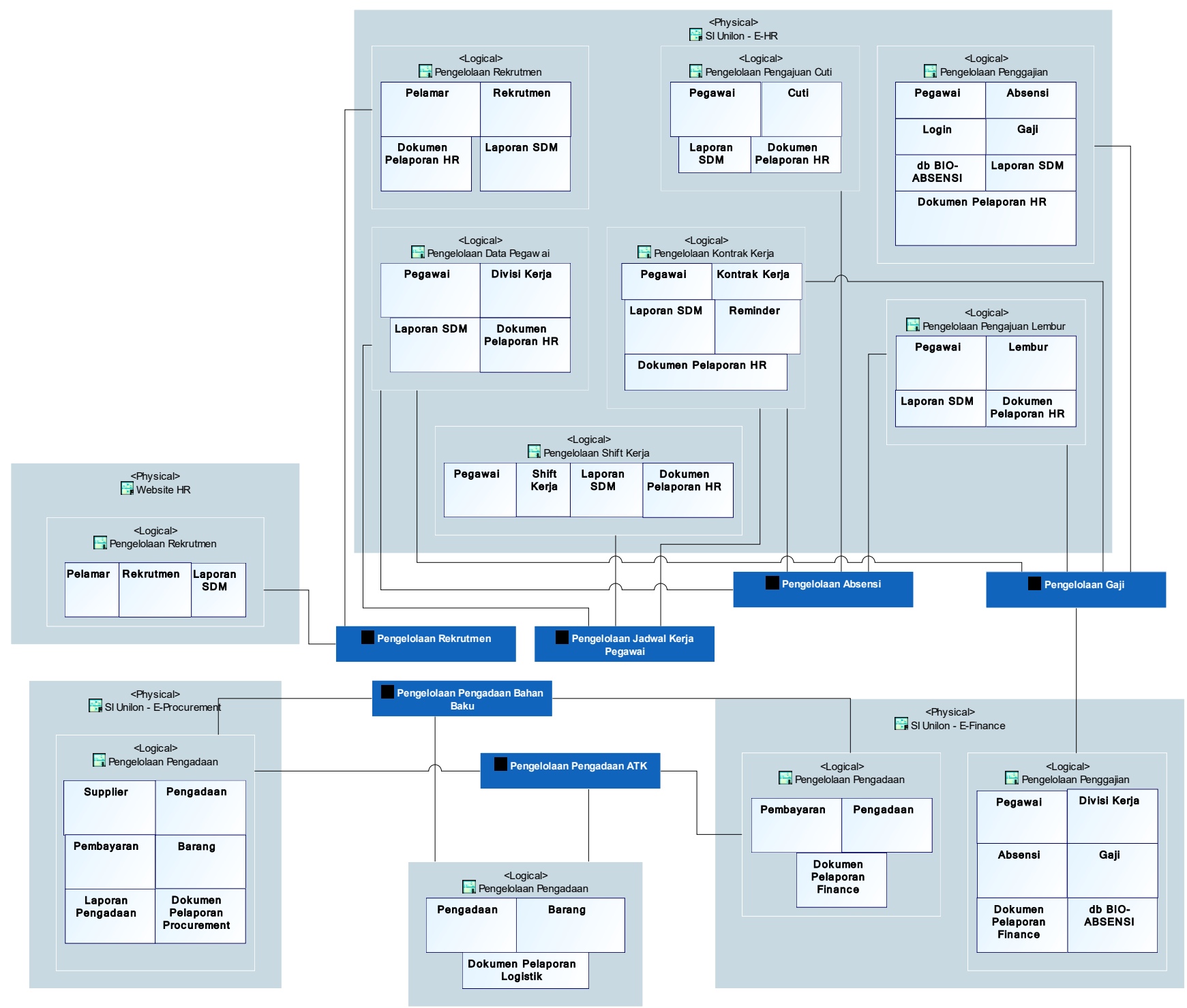

Gambar 4 Data dissemination diagram

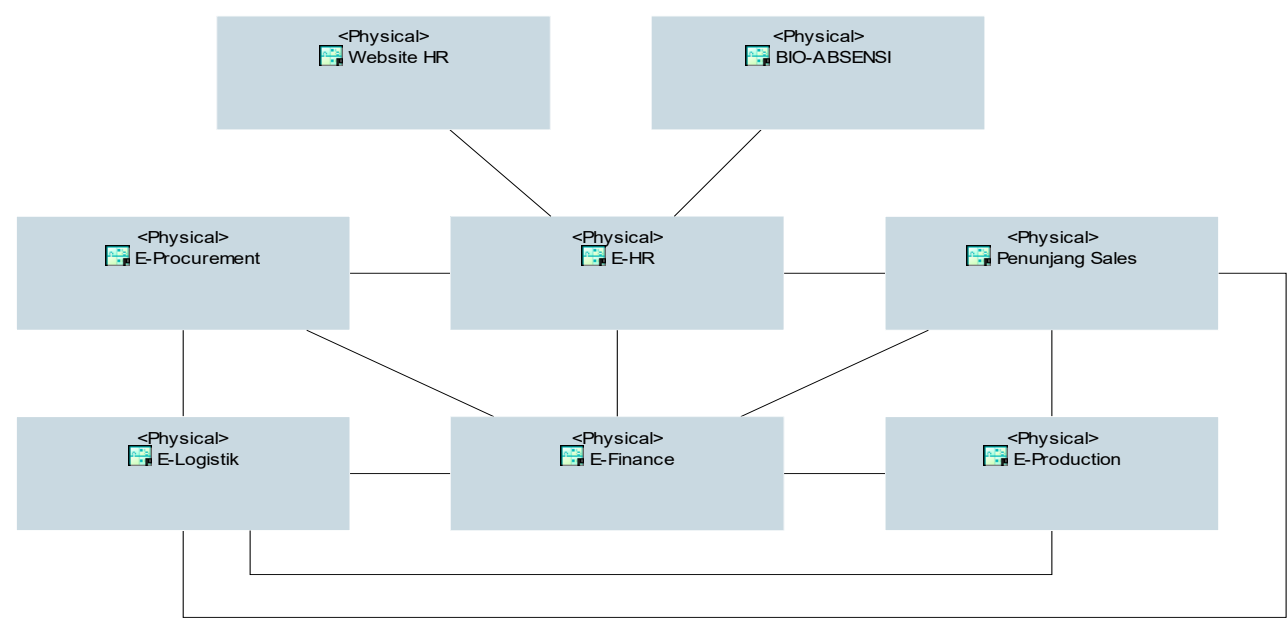

Gambar 5 Application Communication Diagram 


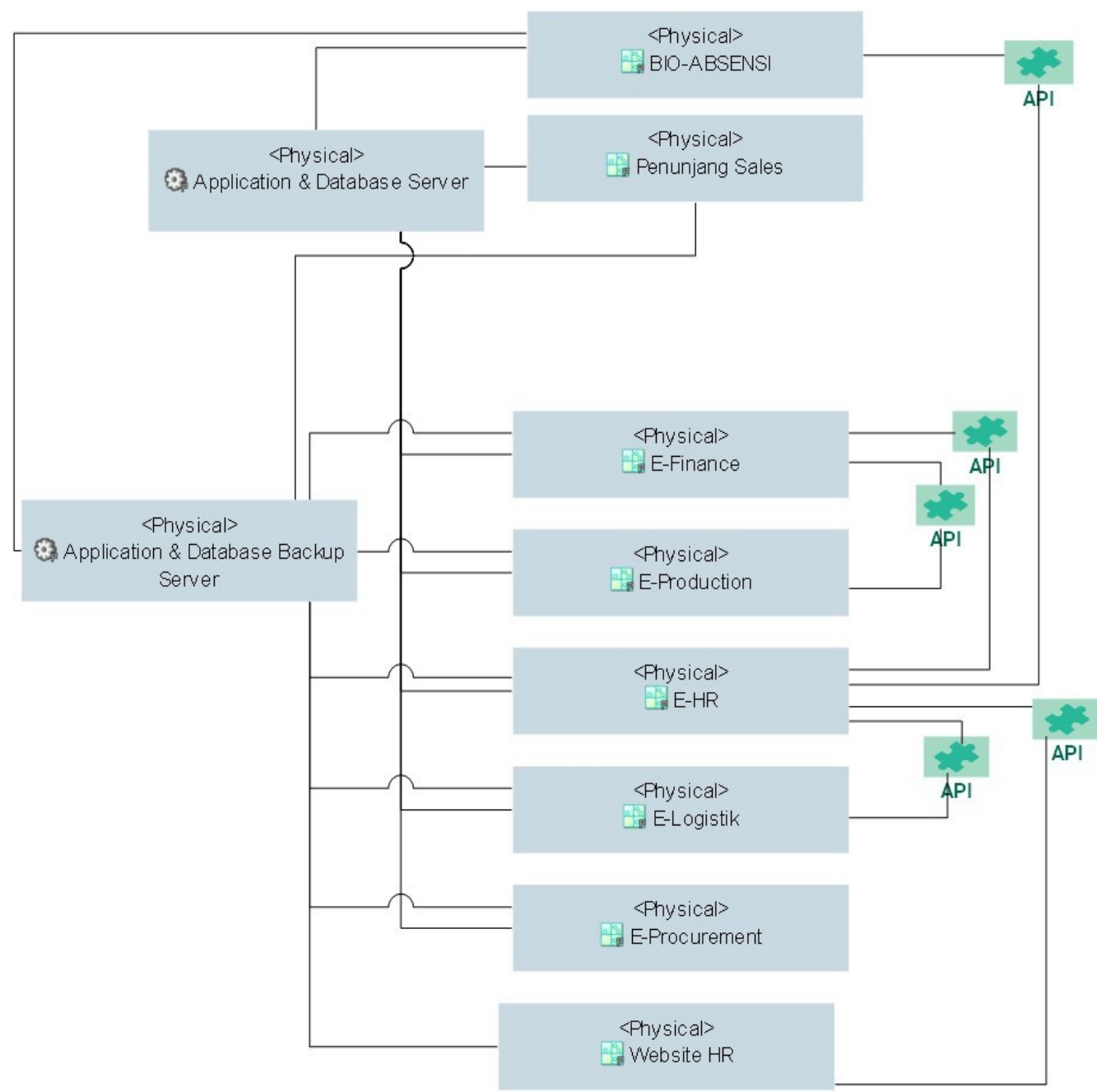

Gambar 6 Platform Decomposition Diagram

\subsection{Fase Opportunities and Solution}

Fase opportunities and solution merupakan acuan dalam implementasi pengembangan enterprise yang telah dirancang pada tahap-tahap sebelumnya. Fase ini menghasilkan implementation factor assessment and deduction matrix yang mendeskripsikan dokumentasi terhadap faktor-faktor yang berpengaruh dalam pengerjaan proyek yang dilakukan. Tabel IV merupakan implementation factor assessment and deduction matrix pada PT Unilon Textile Industries. Adapun proyek yang dirancang untuk penelitian ini hanya sebatas pembuatan modul E-HR untuk menunjang fungsi sumber daya manusia dan pembuatan modul E-Procurement untuk menunjang fungsi pengadaan dapat dilihat pada Tabel V.

\subsection{Fase Migration Planning}

Fase migration planning merupakan proses migrasi dengan menetapkan prioritas proyek berdasarkan resiko dan value yang menghasilkan roadmap dari proses implementasi. Salah satu output yang dihasilkan pada fase ini adalah business value assessment yang menggambarkan hubungan antara value dengan risk berdasarkan proyek TI yang telah dianalisis pada gambar 7. Dari gambar business value assessment dapat dilakukan analisis terhadap prioritas pembangunan proyek sesuai tabel VI dimana menjelaskan tentang prioritas proyek yang akan dibangun terlebih dahulu. Dalam melakukan pertimbangan prioritas proyek, pengembangan infrastruktur menjadi fokus utama karena melibatkan teknologi yang digunakan sebagai penunjang pengembangan integrasi antar aplikasi perusahaan. Berdasarkan tabel VI, maka dibuat IT Roadmap tentang pengembangan proyek dalam kurun waktu tertentu. Pertimbangan estimasi durasi pelaksanaan proyek didasarkan pada scope, resource, dan user requirement. Scope didasarkan pada integrasi modul terhadap fungsi yang diambil. Resources ditentukan dengan sumber daya yang menunjang berjalannya proyek. User requirement didasarkan pada kebutuhan yang harus dipenuhi oleh user. Pada Gambar 8 dijelaskan IT Roadmap yang dihasilkan berdasarkan pertimbangan prioritas proyek. 


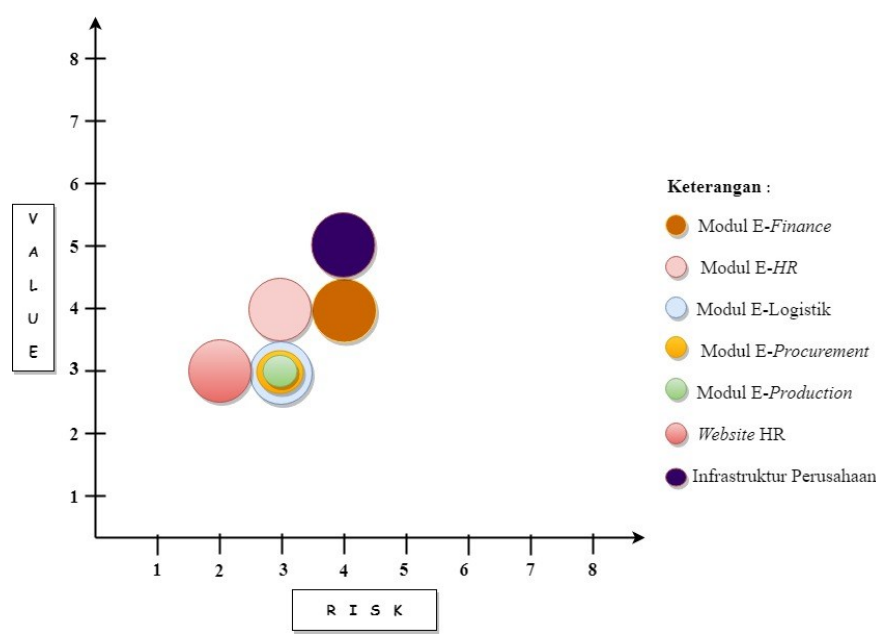

Gambar 7 Business Value Assessment

\subsection{Validasi Penelitian}

Validasi dilakukan untuk mengetahui seberapa efisien integrasi modul sumber daya manusia dan pengadaan dalam menjalankan aktivitas bisnis melalui perancangan enterprise architecture. Validasi ini digunakan untuk memastikan bahwa rancangan keadaan eksisting sesuai dengan keadaan perusahaan saat ini dan rancangan usulan yang diberikan dapat memenuhi kebutuhan perusahaan. Adapun fokus pengambilan data validasi hanya dilakukan pada divisi terkait penelitian ini. Hasil validasi yang dilakukan oleh PT Unilon Textile Industries mengenai integrasi modul yang telah dirancang dapat dilihat pada tabel VII. Simpulan yang didapat dari fase yang telah dijabarkan sebelumnya berupa blueprint perancangan enterprise architecture di PT Unilon Textile Industries untuk mempermudah membaca solusi yang diberikan dalam penelitian ini yang dijabarkan dalam Gambar 9.

Tabel 5

Proyek Arsitektur Target

\begin{tabular}{|c|c|c|}
\hline No & Proyek & Sub Proyek \\
\hline 1 & $\begin{array}{l}\text { Pembuatan Modul E- } \\
\text { Finance }\end{array}$ & $\begin{array}{ll}- & \text { Memperbaiki proses bisnis perusahaan } \\
- & \text { Mengidentifikasi aplikasi yang dibutuhkan } \\
- & \text { Membuat modul E-Finance pada aplikasi Sistem Informasi Unilon } \\
\text { - } & \text { Melakukan percobaan penggunaan modul E-Finance pada aplikasi Sistem Informasi Unilon } \\
\text { - } & \text { Mengimplementasi penggunaan modul E-Finance pada aplikasi Sistem Informasi Unilon } \\
\text { - } & \text { Mengintegrasikan modul E-Finance dengan aplikasi/modul lainnya }\end{array}$ \\
\hline 2 & Pembuatan Website HR & $\begin{array}{ll}- & \text { Memperbaiki proses bisnis perusahaan } \\
- & \text { Mengidentifikasi aplikasi yang dibutuhkan } \\
- & \text { Membuat aplikasi } \\
- & \text { Melakukan percobaan penggunaan aplikasi } \\
- & \text { Mengimplementasi penggunaan aplikasi } \\
- & \text { Mengintegrasikan aplikasi dengan aplikasi/modul lainnya }\end{array}$ \\
\hline 3 & Pembuatan Modul E-HR & $\begin{array}{ll}- & \text { Memperbaiki proses bisnis perusahaan } \\
- & \text { Mengidentifikasi aplikasi yang dibutuhkan } \\
- & \text { Membuat modul E-HR pada aplikasi Sistem Informasi Unilon } \\
- & \text { Melakukan percobaan penggunaan modul E-HR pada aplikasi Sistem Informasi Unilon } \\
- & \text { Mengimplementasi penggunaan modul E-HR pada aplikasi Sistem Informasi Unilon } \\
- & \text { Mengintegrasikan modul E-HR dengan aplikasi/modul lainnya }\end{array}$ \\
\hline 4 & $\begin{array}{l}\text { Pembuatan Modul E- } \\
\text { Procurement }\end{array}$ & $\begin{array}{ll}\text { - } & \text { Memperbaiki proses bisnis perusahaan } \\
- & \text { Mengidentifikasi aplikasi yang dibutuhkan } \\
\text { - } & \text { Membuat modul E-Procurement pada aplikasi Sistem Informasi Unilon } \\
\text { - } & \text { Melakukan percobaan penggunaan modul E-Procurement pada aplikasi Sistem Informasi Unilon } \\
- & \text { Mengimplementasi penggunaan modul E-Procurement } \text { pada aplikasi Sistem Informasi Unilon } \\
\text { - } & \text { Mengintegrasikan modul E-Procurement dengan aplikasi/modul lainnya }\end{array}$ \\
\hline 5 & $\begin{array}{l}\text { Pembuatan Modul E- } \\
\text { Production }\end{array}$ & $\begin{array}{ll}\text { - } & \text { Memperbaiki proses bisnis perusahaan } \\
\text { - } & \text { Mengidentifikasi aplikasi yang dibutuhkan } \\
\text { - } & \text { Melakuat modul E-Production pada aplikasi Sistem Informasi Unilon } \\
\text { - } & \text { Mengimplementasikan penggunaan modul E-Production pada aplikasi Sistem Informasi Unilon } \\
\text { - } & \text { Mengintegrasikan modul E-Production } \text { dengan aplikasi/modul lainnya }\end{array}$ \\
\hline 6 & $\begin{array}{l}\text { Pembuatan Modul E- } \\
\text { Logistik }\end{array}$ & $\begin{array}{ll}\text { - } & \text { Memperbaiki proses bisnis perusahaan } \\
- & \text { Mengidentifikasi aplikasi yang dibutuhkan } \\
- & \text { Membuat modul E-Logistik pada aplikasi Sistem Informasi Unilon } \\
- & \text { Melakukan percobaan penggunaan modul E-Logistik pada aplikasi Sistem Informasi Unilon } \\
- & \text { Mengimplementasikan penggunaan modul E-Logistik pada aplikasi Sistem Informasi Unilon } \\
- & \text { Mengintegrasikan modul E-Logistik dengan aplikasi/modul lainnya }\end{array}$ \\
\hline
\end{tabular}

Tabel 6

Pembangunan Prioritas Proyek

\begin{tabular}{clc}
\multicolumn{1}{c}{ Solusi } & Estimasi Value \\
\hline No & & 1 \\
2 & Proyek Perbaikan Infrastruktur & 2 \\
3 & Proyek Pembuatan Modul E-Finance & 3 \\
4 & Proyek Pembuatan Modul E-HR & 4 \\
5 & Proyek Pembuatan Modul E-Logistik & 5 \\
6 & Proyek Pembuatan Modul E-Procurement & 6 \\
7 & Proyek Pembuatan Website HR & 7 \\
\hline
\end{tabular}


Tabel 7

Validasi Perancangan Enterprise Architecture

\begin{tabular}{|c|c|c|c|c|c|c|}
\hline \multirow[b]{2}{*}{ Pertanyaan } & \multicolumn{5}{|c|}{ Nilai } & \multirow{2}{*}{$\begin{array}{l}\text { Persentase } \\
\text { (Nilai } x \text { 20) } \\
(\%)\end{array}$} \\
\hline & 1 & 2 & 3 & 4 & 5 & \\
\hline \multicolumn{7}{|c|}{ Business Architecture } \\
\hline $\begin{array}{l}\text { Requirement business sesuai dengan kebutuhan bisnis PT Unilon } \\
\text { Textile Industries }\end{array}$ & & & & & $\mathrm{V}$ & $100 \%$ \\
\hline $\begin{array}{l}\text { Perancangan proses bisnis eksisting khususnya pada process flow } \\
\text { diagram sesuai dengan kondisi eksisting di perusahaan saat ini }\end{array}$ & & & & & $\mathrm{V}$ & $100 \%$ \\
\hline $\begin{array}{l}\text { Proses bisnis yang diusulkan sesuai dengan kebutuhan bisnis PT } \\
\text { Unilon Textile Industries }\end{array}$ & & & & & $\mathrm{V}$ & $100 \%$ \\
\hline $\begin{array}{l}\text { Proses bisnis yang diusulkan dapat mendukung aktivitas yang } \\
\text { dijalankan PT Unilon Textile } \\
\text { organisasi }\end{array}$ & & & & & $\mathrm{V}$ & $100 \%$ \\
\hline $\begin{array}{l}\text { Proses bisnis yang diusulkan sesuai dengan prinsip PT Unilon Textile } \\
\text { Industries yaitu berorientasi layanan }\end{array}$ & & & & & $\mathrm{V}$ & $100 \%$ \\
\hline \multicolumn{7}{|c|}{ Data Architecture } \\
\hline $\begin{array}{l}\text { Requirement data sesuai dengan kebutuhan data yang diperlukan pada } \\
\text { proses bisnis usulan }\end{array}$ & & & & & $\mathrm{V}$ & $100 \%$ \\
\hline $\begin{array}{l}\text { Kesesuaian entitas data usulan dengan kebutuhan data dalam } \\
\text { menjalankan proses bisnis usulan }\end{array}$ & & & & & $\mathrm{V}$ & $100 \%$ \\
\hline $\begin{array}{l}\text { Hubungan antar entitas data sesuai dengan kebutuhan data dalam } \\
\text { menjalankan proses bisnis usulan }\end{array}$ & & & & & $\mathrm{V}$ & $100 \%$ \\
\hline \multicolumn{7}{|c|}{ Application Architecture } \\
\hline $\begin{array}{l}\text { Requirement application sesuai dengan kebutuhan aplikasi dalam } \\
\text { menjalankan proses bisnis usulan }\end{array}$ & & & & & $\mathrm{V}$ & $100 \%$ \\
\hline Kesesuaian fungsi aplikasi dalam mendukung proses bisnis usulan & & & & & $\mathrm{V}$ & $100 \%$ \\
\hline $\begin{array}{l}\text { Hubungan antar aplikasi sesuai dalam melakukan pertukaran data } \\
\text { untuk menjalankan proses bisnis }\end{array}$ & & & & & $\mathrm{V}$ & $100 \%$ \\
\hline $\begin{array}{l}\text { Aplikasi yang diusulkan mampu beoperasi pada berbagai platform } \\
\text { teknologi }\end{array}$ & & & & & $\mathrm{V}$ & $100 \%$ \\
\hline \multicolumn{7}{|c|}{ Technology Architecture } \\
\hline $\begin{array}{l}\text { Requirement technology sesuai dengan kebutuhan teknologi dan } \\
\text { infrastruktur dalam mendukung arsitektur sistem informasi yang } \\
\text { diusulkan }\end{array}$ & & & & & V & $100 \%$ \\
\hline $\begin{array}{l}\text { Kesesuaian komponen teknologi untuk mendukung berjalannya } \\
\text { arsitektur sistem informasi yang diusulkan }\end{array}$ & & & & & $\mathrm{V}$ & $100 \%$ \\
\hline $\begin{array}{l}\text { Kesesuaian antar komponen teknologi dalam mendukung jalannya } \\
\text { arsitektur sistem informasi yang diusulkan }\end{array}$ & & & & & $\mathrm{V}$ & $100 \%$ \\
\hline $\begin{array}{l}\text { Teknologi yang diusulkan mampu menanggapi perubahan kebutuhan } \\
\text { bisnis PT Unilon Textile Industries }\end{array}$ & & & & & $\mathrm{V}$ & $100 \%$ \\
\hline $\begin{array}{l}\text { Teknologi yang diusulkan dapat meningkatkan kinerja aplikasi } \\
\text { eksisting atau yang diusulkan }\end{array}$ & & & & & V & $100 \%$ \\
\hline $\begin{array}{l}\text { Teknologi yang diusulkan mampu mengurangi permasalahan dalam } \\
\text { pengelolaan data }\end{array}$ & & & & V & & $80 \%$ \\
\hline $\begin{array}{l}\text { Total Nilai Persentase (\%) } \\
\text { (Jumlah Persentase Nilai / Jumlah Pertanyaan }\end{array}$ & & & & & & $98.88 \%$ \\
\hline
\end{tabular}

Tabel 8

Roadmap

\begin{tabular}{|c|c|c|c|c|c|c|c|c|c|c|c|c|c|c|c|c|c|c|}
\hline \multirow{3}{*}{ No } & \multirow{3}{*}{ Proyek } & \multirow{3}{*}{$\begin{array}{c}\text { Estimasi } \\
\text { Durasi }\end{array}$} & \multicolumn{16}{|c|}{ Periode } \\
\hline & & & \multicolumn{4}{|c|}{ Tahun ke-1 } & \multicolumn{4}{|c|}{ Tahun ke-2 } & \multicolumn{4}{|c|}{ Tahun ke-3 } & \multicolumn{4}{|c|}{ Tahun ke-4 } \\
\hline & & & T1 & T2 & T3 & T4 & T1 & T2 & T3 & T4 & T1 & T2 & T3 & T4 & T1 & T2 & T3 & T4 \\
\hline 1 & $\begin{array}{l}\text { Pembuatan Perbaikan } \\
\text { Infrastruktur }\end{array}$ & 9 Bulan & & & & & & & & & & & & & & & & \\
\hline 2 & $\begin{array}{l}\text { Pembuatan Modul E- } \\
\text { Finance }\end{array}$ & 8 Bulan & & & & & & & & & & & & & & & & \\
\hline 3 & Pembuatan Modul E-HR & 7 Bulan & & & & & & & & & & & & & & & & \\
\hline 4 & $\begin{array}{l}\text { Pembuatan Modul E- } \\
\text { Logistik }\end{array}$ & 7 Bulan & & & & & & & & & & & & & & & & \\
\hline 5 & $\begin{array}{l}\text { Pembuatan Modul E- } \\
\text { Procurement }\end{array}$ & 6 Bulan & & & & & & & & & & & & & & & & \\
\hline 6 & $\begin{array}{l}\text { Pembuatan Modul E- } \\
\text { Production }\end{array}$ & 6 Bulan & & & & & & & & & & & & & & & & \\
\hline 7 & Pembuatan Website HR & 5 Bulan & & & & & & & & & & & & & & & & \\
\hline
\end{tabular}


Fadilah, B.R., dkk. Jurnal Rekayasa Sistem dan Industri Volume 05 No 02 (2018)

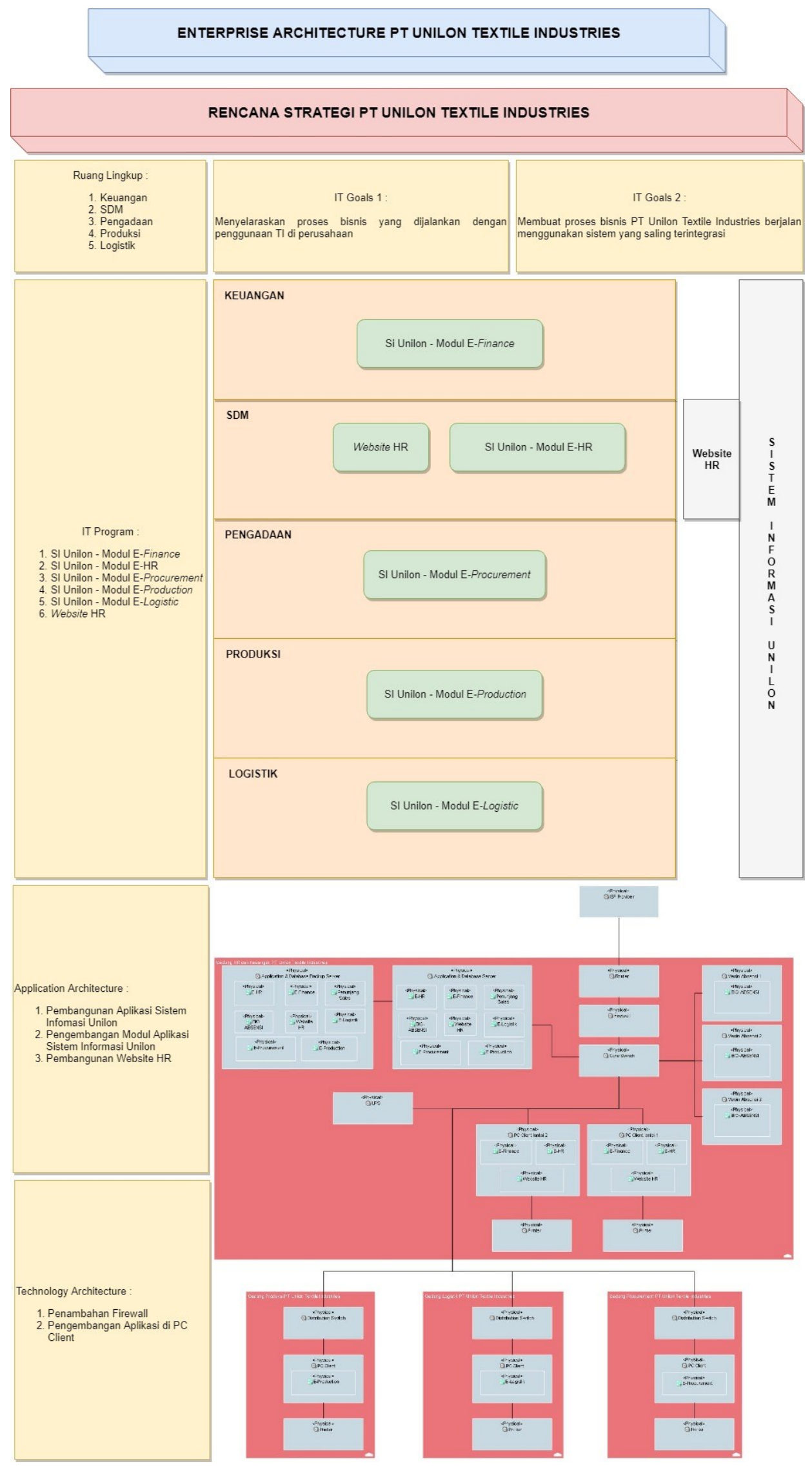

Gambar 9 Blueprint Enterprise Architecture PT Unilon Textile Industries 


\section{Kesimpulan}

Analisis terhadap kondisi eksisting perancangan enterprise architecture fungsi SDM dan pengadaan belum memenuhi requirement perusahaan baik dari proses bisnis eksisting, entitas data, penggunaan aplikasi, serta teknologi yang digunakan pada perusahaan sehingga diperlukan perbaikan dan pengembangan dalam menunjang proses bisnis yang dijalankan pada perusahaan. Berdasarkan hasil perancangan enterprise architecture yang telah dilakukan pada fungsi sumber daya manusia dan pengadaan terdapat usulan berupa penambahan aplikasi Sistem Informasi Unilon. Sistem Informasi Unilon didalamnya mengintegrasikan seluruh modul yang digunakan pada fungsi-fungsi di perusahaan. Rancangan enterprise architecture yang telah dibuat berupa integrasi modul akan dijadikan sebagai landasan dalam mengembangkan pemanfaatan TI dengan menyesuaikan kebutuhan bisnis yang diperlukan PT Unilon Textile Industries. Validasi terhadap blueprint IT didasarkan pada scope, resource, dan user requirement yang terintegrasi pada modul sumber daya manusia dan pengadaan dapat membuat proses bisnis yang dijalankan perusahaan menjadi efektif sebesar $98.88 \%$

\section{Referensi}

[1] Hutama, Y., Arman, A. A., \& Romansyah, Y. (2014). Perancangan Enterprise Architecture Menggunakan Framework 9.0 dan Content Framework (Studi Kasus BAA Universitas Kristen Maranatha). Electrical Engineering Journal, 45-62..

[2] Irfanto, R., \& Andry, J. F. (2017). Perancangan Enterprise Architecture Menggunakan Zachman Framework (Studi Kasus : PT. Vivamas Adipratama). Seminar Nasional Sains dan Teknologi.

[3] Group, T. O. (2009-2011). TOGAF Version 9.1. U.S.

[4] Mardiansyah, C. R. (2012). Analisis dan Pengembangan Enterprise Architecture Menggunakan Framework TOGAF Pada Pengedilan Agama Bandung.

[5] Osvalds, G. (2001). Definition od Enterprise Architecturecentric Models for the Systems Engineer. International Council on Systems Engineering (INCOSE).

[6] Setiawan, E. B. (2009). Pemilihan EA Framework. Seminar Nasional Aplikasi Teknologi Informasi 2009 (SNATI 2009).

[7] Ersa Novia Fajrin, Y. A.-A. (2016). Perancangan Enterprise Architecture Pada Bidang Sumber Daya Manusia dan Organisasi Serta Bidang Komunikasi Hukum dan Administrasi PT PLN Distribusi Jawa Barat Menggunakan Framework TOGAF ADM. e-Proceeding of Engineering, 3149. 